依 頼 論 文

•日本補綴歯科学会第 120 回記念学術大会 /ジョイントシンポジウム 1

「CAD/CAM から Digital Dentistry ヘーコンピュータを応用した歯科治療の最前線一」

\author{
ジルコニアを理解し，包括的に幅広く歯科臨床へ応用する \\ 一材料をいかに生かして補綴装置を作り上げるか一
}

増田 長次郎

\title{
Understanding Zirconia and Comprehensively Applying It to a Wide Dental Practice
}

\author{
Chojiro Masuda
}

\begin{abstract}
抄 録
補綴治療における予知性と審美性の両立は, 外科術式や補綴の技術革新により, 可能かつ容易となった。 歯列の連続性を回復し, 顎口腔機能へアプローチしたうえで審美性を確立していかなければならない.

歯科材料の目覚しい発展によって, 外科術式や補綴の選択肢・優位性が向上したことは周知の事実であ る。特に，CAD/CAM の進歩により，審美修復およびインプラント修復の幅が大きくなった。しかしな がら，それらが先行するあまり，本来の患者本位の歯科医療の分野が置き去りにされていないかを本項に おいて再考してみたい. 今回は新素材ジルコニアに焦点を絞り, 強度や光透過性や組織親和性などその特 性を紹介するとともに, ジルコニアフレームの特徵を最大限引き出すための手法, さらにはインプラント （アバットメント）も含めた幅広い臨床応用や留意点について解説する.

チェアーサイドとラボの役割分担を明確にし，同じ意識で一人の患者・一つの模型に取り組むことが重 要であり, 検査・診断・治療計画から, 審美性と機能の回復, メインテナビリティの確立のために何が必 要かを示していきたい.
\end{abstract}

和文キーワード

審美修復，ジルコニア，CAD/CAM

\section{I 。はじめに}

歯科医療はトップダウントリートメントとボトムアッ プトリートメントを再評価しながら繰り返されていく。 それは, 顔面 (全身), 咬合単位 (下顎位・顎関節・咬 合), 歯列, 歯牙単位もしくはインプラント単位の順に, 検査・診断し, 診療体系に組み込まれていかなければな らない，そして，歯科補綴装置を製作するうえでの 3 因子として, 審美性（骨・軟組織の環境整備, 修復的審 美), 顎口腔機能, 材料 (理工) があげられる. そこに はチェアーサイドとラボサイドの包括的な配慮が求めら れる。 それらの何かが欠けても, 長期に維持・安定した 修復は難しい.また, 歯牙の位置やインプラントの位置・ 深度・傾斜, 材料学的背景など, 構造的配慮が必要であ ることも加えて前置きしておきたい.
本稿では，昨今話題のジルコニアに特化し，その補足 として包括的に補綴装置を捉えていきたい.

\section{II．まず，ジルコニアを理解する}

世界各国において，多くのメーカーによってジルコニ ア素材が開発・販売されている。歯科におけるジルコニ ア素材は，そのほとんどが日本国内で生産されており， 酸化ジルコニウム $\left(\mathrm{Z}_{\mathrm{r}} \mathrm{O}_{2}\right)$ 94.4\%, 酸化イットリウム $\left(\mathrm{Y}_{2} \mathrm{O}_{3}\right) 5.4 \%$ ，その他 $0.2 \%$ にて構成されている。 そ れらは Blatzのせん断試験 ${ }^{1)}$ により検証されているよ うに, 結果的に, 臨床上剥離していないことを考えると, せん断試験デー夕と併せて歯科用貴金属合金との焼付け 以上の結果とみなしている (図 1, 図 2).

メタルボンドクラウン (PFM) に使用する金合金と 比較して, 生産性・物性的・価格的に安定した材料とし 


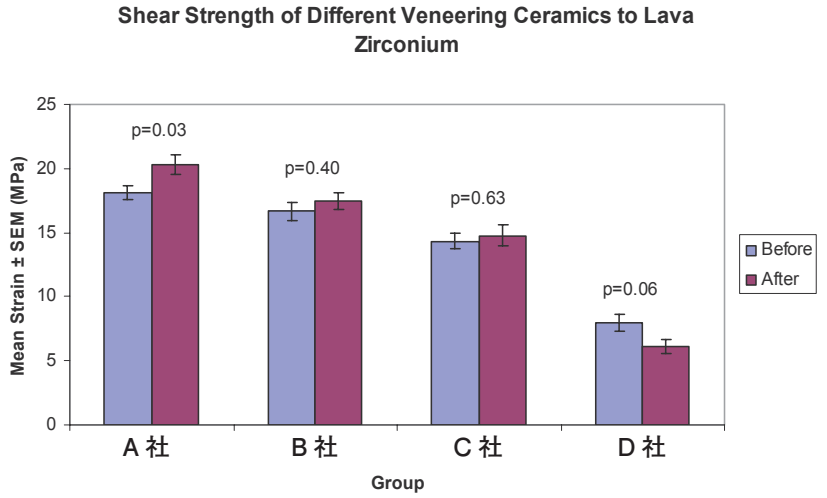

図 1 ベニアと陶材のジルコニアに対するせん断焼付け強 度 ${ }^{1)}$

$\mathrm{A}$ 社， B 社， C 社はジルコニア，D 社は金属と陶材.

てのジルコニアではあるが，焼結後の非常に高い硬度に より切削効率の悪さが指摘されてきた。 そこに CAD/ CAM 技術の向上により, 仮焼結ブロックや未焼結ブロ ックを切削することが可能となった. 工業界はもとよ り，ジルコニアの開発は，そういつた世界的経済事情が 背景にあることは興味深い。

\section{III. ジルコニアの特性として活かすべき点}

\section{1. 利点}

・製作が単純.

・発色が簡単（反射光・透過光を有する）.

・色調が淡黄色で，審美材料として優れている.

・金属アレルギーが少ない.

・生体親和性（自浄作用）が高い.

・セラミック材料であり，貴金属材料のように価格変動 が少ない.

・支台歯の色調を反映できる.

\section{2. 欠点}

・適応範囲を選ぶ（現在のところ，ろう付けができない ので，ロングスパンの適合が困難).

・経年的強度・耐久性への不安定感。

・臨床的経験が少ない.

・支台歯（形成・色調）の影響を受ける。

\section{IV.シェードテイク時の注意事項}

\section{1、撮影に関する注意事項}

基本的にデジタルで情報交換を行う. 歯科医院とラボと の光の環境を補正(統一)するために画面上で環境を整え る必要がある. カメラ撮影に関し注意事項がある(図 3).

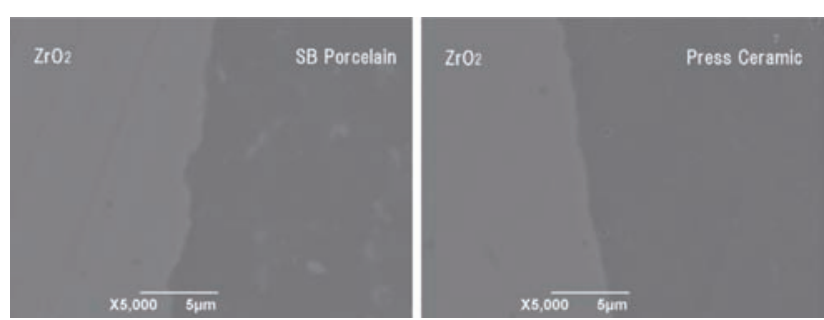

図 2 ジルコニアコーピングと専用陶材並びにプレスセラ ミックの界面 SEM 像

・色調を再現したい歯牙とシェードガイド 2〜3 本を, 切縁どうしで重ならないようにカメラと被写体・シ エードガイドは垂直に合わせる。

・色調を再現したい歯牙とシェードガイドを，同じ深度 にする。対象物との深度が違うと, 明度・彩度が正確 に表現できない.

・色調を再現したい歯牙とシェードガイド，合わせてキ ヤスマッチを取り込むと再現精度がさらに向上する。

• 天然歯の場合，歯牙がすぐに乾燥・白色化するため, 開口後, 支台歯形成前に可及的速やかな撮影が要求さ れる。厳密には約 1 分以内とされているが，時間が 経過したと思ったら，再度閉口状態を維持するか，水 などで湿らせる。

・被写体のハレーションには十分な注意を払いたい。サ イド(ツイン)フラッシュのカメラでなら問題ないが,

リングフラッシュの場合は，角度を変えて（切縁側寄 り・根尖側寄り，近緑心寄り）撮影すると大きな参考 になる。

・被写体の背景を黒色にし，できるだけ大きく撮影す る.

\section{2. 支台の材質 ・色調情報}

オールセラミックスの材質によっては，大きく支台の 色調を反映する。健全歯・失活歯（変色歯)，金属コア （銀色・金色）・ファイバーコアなどの情報をラボサイ ドに伝達する必要がある。しかるべき処理をしたり, 最 適な各種オールセラミックスマテリアルを提案すること になる，よって，シェードを撮影するときに，一緒に支 台のみの写真も必要である.

\section{V． 材料の弱点とその対処法 一材料による症例の選択一}

\section{1. 光の透過性}

日本においてもさまざまなマテリアルが市場を賑わせ ているなか, 各社多様な成型技術により透過性の違う材料 
〈推 奨〉

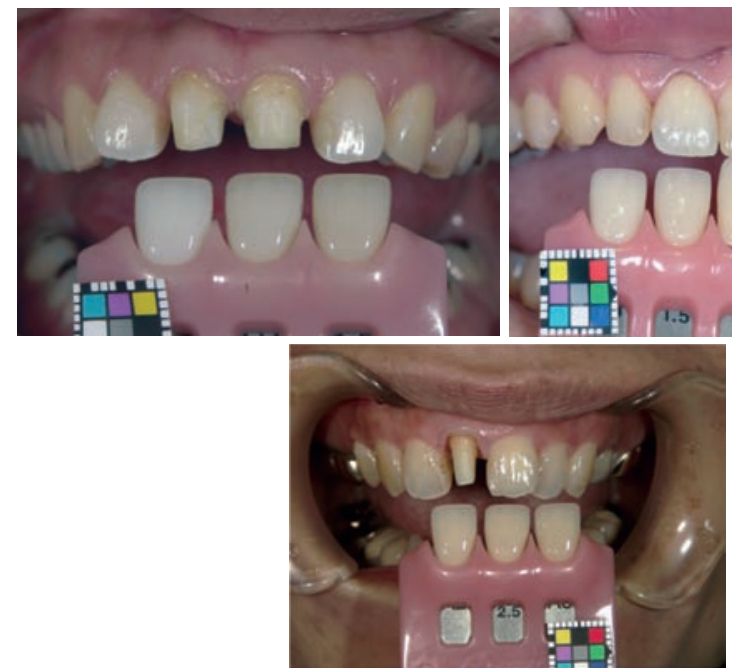

補正前
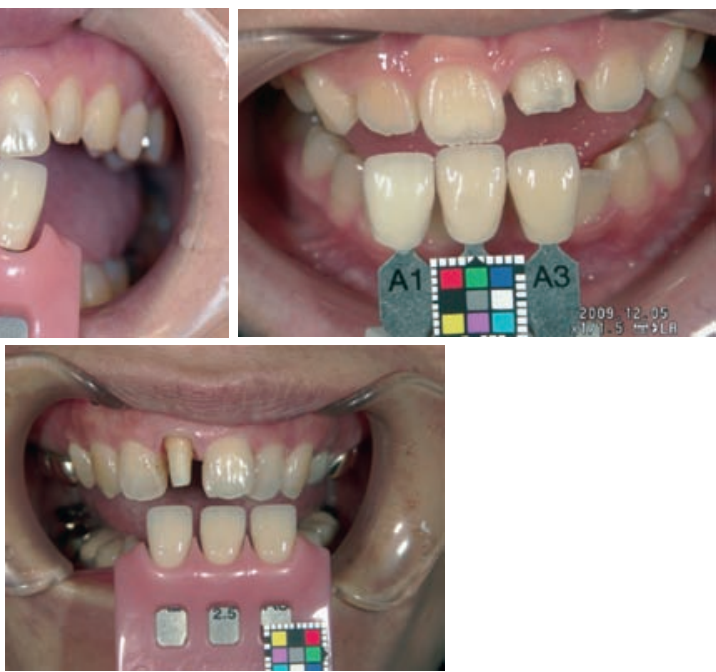

補正後

〈良〈ない例〉

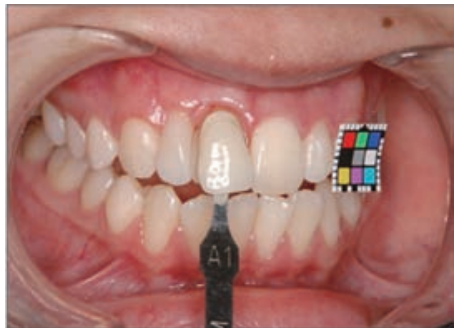

対象歯牙にガイドが被っている

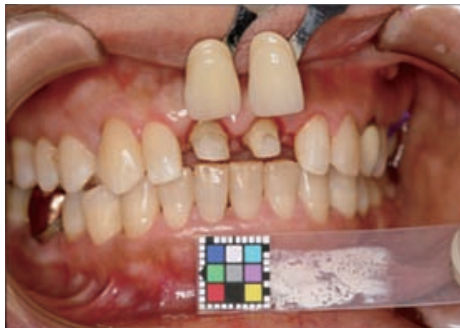

ガイドが逆向き

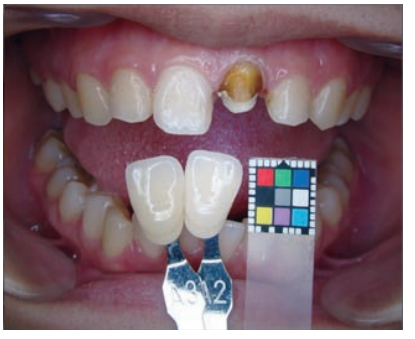

ハレーション・暗い

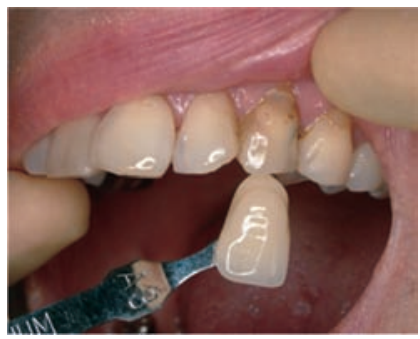

ガイドが逆向き

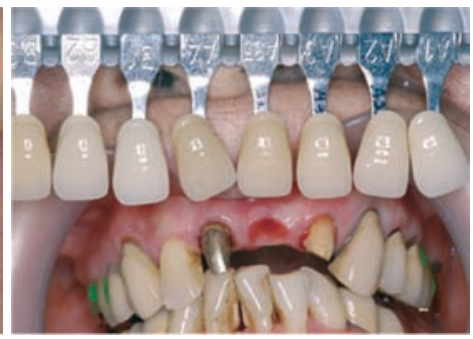

ガイドが逆向き・どの色?

図 3 シェードテイクの参考例

が販売されている. 図 4 は試験片の厚みと透過率を表し たグラフである.アルミナや, 強化型ガラスセラミックス や, PFM, そしてこれらの各種ジルコニアコーピングも 特徵をしつかり理解して使い分ける必要がある (図 5).

Yoshida の検証にもあるように (表 1$)^{2)}$, 適度な透 光性はジルコニアクラウンの大きな優位性ではあるが, 支台歯の変色や金属支台の場合それらの色調を反映して しまう。図 6, 図 7 の写真は, ジルコニアコーピング 内面にシルバー色のスペーサーを塗布し, 金属支台や変 色支台を想定しその影響を比較してみたものである. 左 半分は, ある程度の遮光性を有するシェードベース (SB)
とオペーシャスボディーを $1: 1$, 右半分はオペーシャ スボディーを単体でマスキングした. その後, ボディー・ エナメル・トランスの各陶材合計 $1 \mathrm{~mm}$ を築盛しその 違いを比較したところ, 明らかに違いが出た. 必要に応 じてする SB を使用することにより，変色支台の影響を 食い止めることができる。 また, 将来, 支台歯が変色す る可能性がある場合にも有利と思われる。ジルコニア コーピングはある程度の光透過性を有し，それが利点に も欠点にもなることを認識しておきたい.

有機質の特徵として, 適度な透光性と反射により，ま たそれらが拡散することで明るさを表現する。よって， 


\section{ジルコニアブロックの透過率比較}

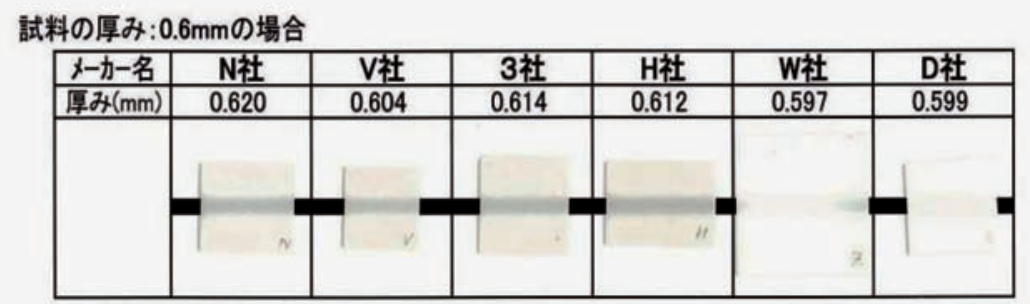

\section{試料の厚み: $0.4 \mathrm{~mm}$ の場合}

\begin{tabular}{|c|c|c|c|c|c|c|}
\hline x-か-名 & N社 & V社 & 3社 & H社 & W社 & D社 \\
\hline 厚み(mm) & 0.415 & 0.412 & 0.408 & 0.411 & 0.405 & 0.408 \\
\hline & & & & & & \\
\hline & & & & & & \\
\hline
\end{tabular}

図 4 各社透過率比較表. 日立製作所社製，分光光度計 U-3000 を使用し， JIS K-361-1 の条件で測定。試料の厚みは 0.4 mm と $0.6 \mathrm{~mm}$.

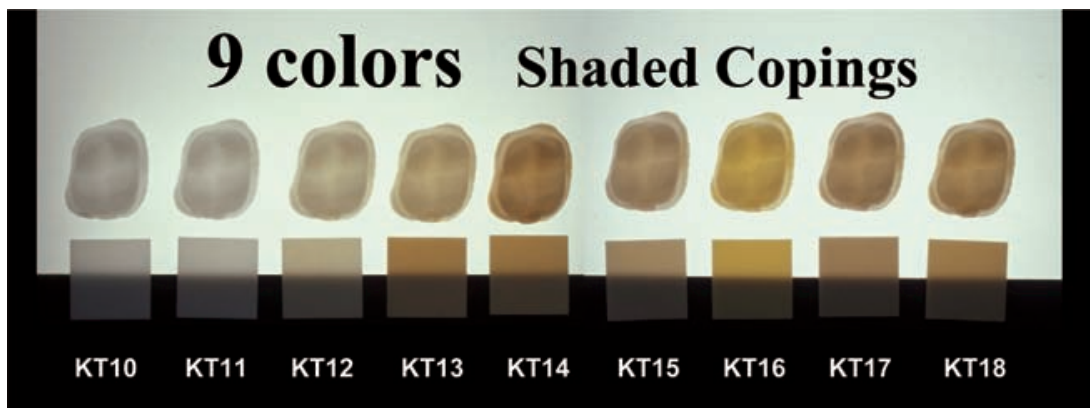

図 5 ノリタケKatana コーピングの透過光試験

表 1 Material translucency (\% light transmission) ${ }^{2)}$

\begin{tabular}{cccccc}
\hline Feldspar & In-Ceram Spinell & Procera & Zirconia & In-Ceram Alumina & Metal \\
\hline $46 \%$ & $37 \%$ & $33 \%$ & $27 \%$ & $16 \%$ & $0 \%$ \\
\hline
\end{tabular}

ジルコニアの明るさは，ただ単に白いだけではなく，適 度な透光性が発生することによることにも起因する（図 8).PFM の場合，光の透過を許さない金属の裏装と才 ペークの使用により，焼付用陶材の範囲において，その 透過と反射を表現しなければならないという困難な作業 が強いられる。逆に，反射をほとんど有しない，もしくは 裏装されていない透過性の高い材質は，暗く感じるのは そのためである。適度な透過性を有する酸化ジルコニウ ムによって，明るさという観点から考えれば，光を拡散 させられるというその特徴を生かしていきたいと思う。

\section{2. 破折}

ポーセレンチップが発生する要因として，下記のよう なものが考えられる。

・咬合

・フレームデザインが不適切（=ポーセレンの築盛量が 不均一)

・フレームとの焼成連結強度不足（表層陶材の成分）

・フレームの表面処理不良

Christensen は Clinician Report で，装着後 2 年間 

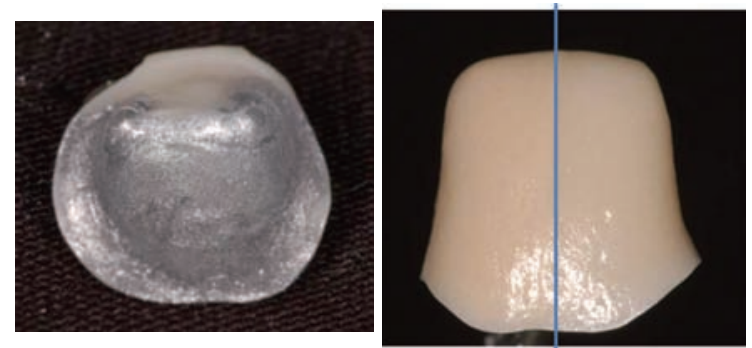

$\mathrm{SB}: \mathrm{OB}=1: 1 \quad \mathrm{OB}$

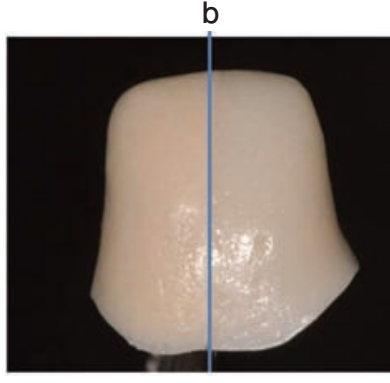

$\mathrm{SB}: \mathrm{OB}=1: 1$

OB

図 6 ジルコニアコーピングの透過性テスト

a : スペーサー裏装無し

$\mathrm{b}$ : スペーサー裏装あり

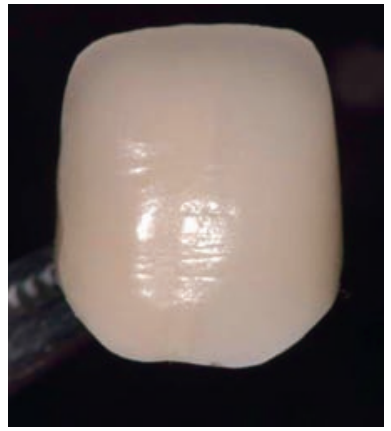

図 7 ボディー・エナメル・トランスをコーピング込みで $1 \mathrm{~mm}$ の厚みで焼成

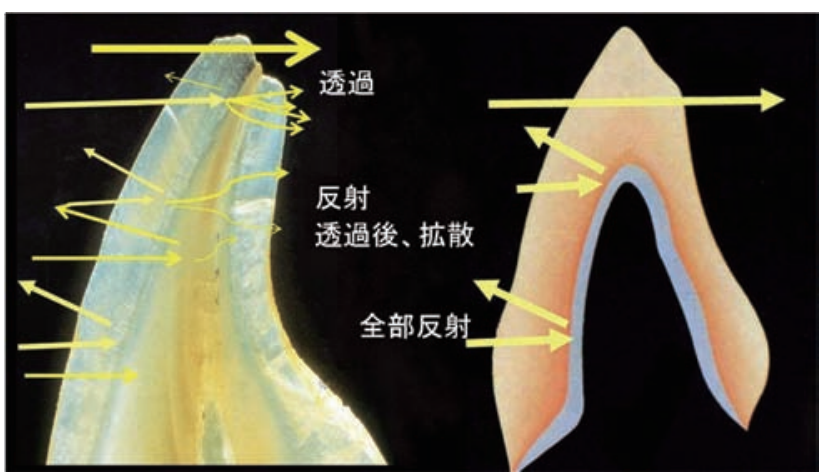

図 8 光の透過と反射

に臼歯 3 本ブリッジ修復物の 293 症例を口腔内追跡調 査し，ジルコニアフレーム自体の破切はほとんどなく， 表層ポーセレンのチッピングやクラックや剥離が, PFM と比べかなりの頻度で発生していることを報告してい る ${ }^{3)}$. 原因として，まず咬合管理があげられるであろう。

次に，ジルコニアコーピングが支台歯に対して一定の 厚みを付与することによって，最終外形に至るポーセレ ンの厚みが不均一であることがあげられるであろう。こ れは，ジルコニアブリッジだから破折やチッピングを引 き起こすのではなく，PFM でも同じことが言えるのは
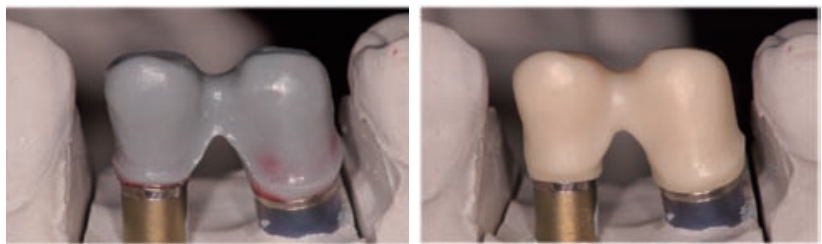

図 9

周知の事実であろう。PFM を作製する場合，最終外形 をワックスアップしてからカットバックするのと同じよ うに，ジルコニアクラウンも同等の取り扱いをしなけれ ばならない. CAD 技術の向上により，あらかじめ用意 したワックスアップを読み込んだり（図 9)，大まかな 外形をシュリンクさせた形状 (図 10) を表現できたり, CAD 上でデザインができる。言い換えれば，それらの 工夫をしなければ問題が発生するものと捉えるべきであ ろう。ジルコニアの長期安定性については，ジルコニア は高温では正方晶だが， $1170^{\circ} \mathrm{C}$ 以下で相変化を生じ単 斜晶になり，4\% 膨張することからクラックなどの問題 を生じ，これを防止するために 3 モルイットリアが添 加されている。 しかし，水分残存下では，すなわち口腔 内では $\mathrm{OH}$ 基によって Zr-O の結合が分断され，正方 晶の安定性がくずれ単斜晶に変態し，劣化することが懸 念される。

現在，ジルコニアは臨床応用されてから約 10 年ほど で,この低温劣化に対して長期的観察が必要と思われる.

陶材は $\mathrm{S}_{\mathrm{i}} \mathrm{O}_{2}$ が主成分で，それだけでは十分な強度は

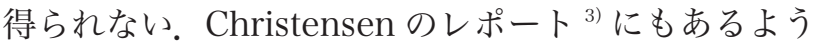
に，筆者としては抗折強度を論じるよりも，破壊鞀性值 に着眼するほうが得策だと思う。

繰り返し述べるが，補綴装置とは，究極の言い方をす れば，人工臓器である以上，審美性のみがクローズアッ プされるようではいけない. 長期に安定した機能が発揮 されなければならない。 


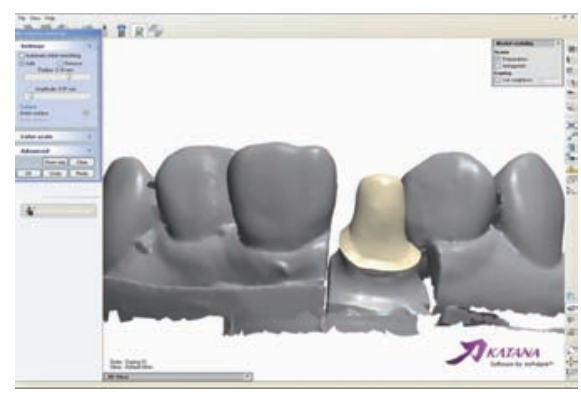

a

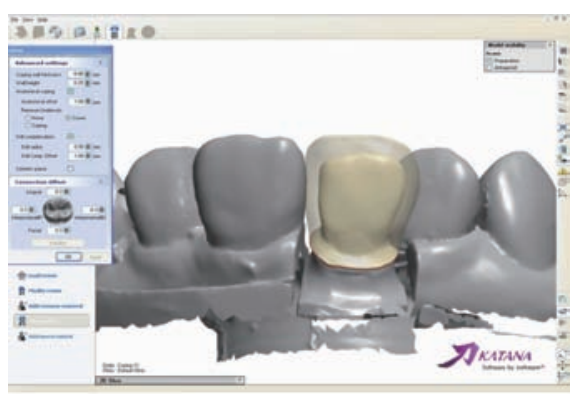

b

図 10 築盛陶材の均一な厚みになるようにコーピングを製作 $\mathrm{a}$ ：支台歯なりのコーピング

$\mathrm{b}$ : 陶材の厚みが均一になるコーピング形状
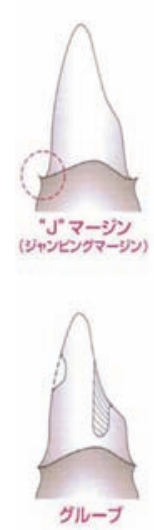

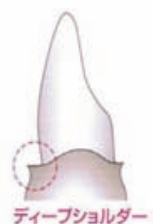

ティープンヨルター

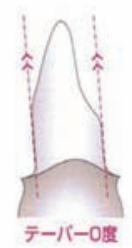

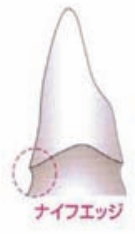

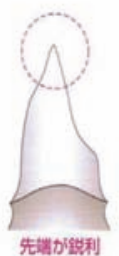

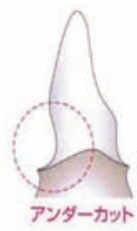
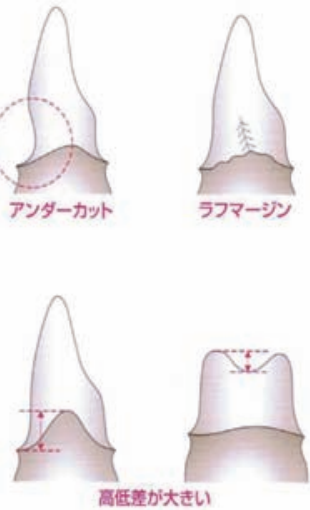

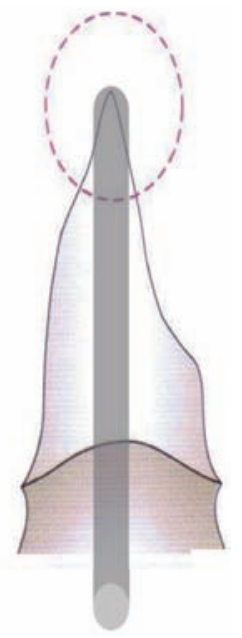

図 11 適合精度に不利な形成

\section{VI. 適合精度の向上における注意点}

CAD と CAM 双方の機械精度やマテリアルの優劣に 影響されることは当然であるとして, 医療現場の注意点 としては支台歯形成が挙げられる。適合精度に不利な形 成例として下記に表記した。いつかの CAD システム の性質上，それら以外にも，滑らかな形成面や表面性状 が求められる。現状のスキャンシステムでは，レーザー スキャン方式や接触方式がとられる。 多くの場合, ジル コニアブロックを切削バーで削りだしていくため（図 11）に切縁まで切削するには，バーの直径分だけの空 洞を生じざるを得ない. 特に唇舌側や咬合面などに十分 なクリアランスがない場合は, 表層ポーセレンの厚みが 確保できないために色調表現が困難になったり，コーピ ングを削合することによって, 十分な強度の保証が出来 なくなる。.よって, 支台歯全域において極力角のない丸 みを帯びた形成が要求される。

\section{VII. 製作工程で重視する事項}

ジルコニアフレームを調整するとき，急激で過度な過 熱は避けなければならない。これは, 熱伝導率が低いこ とから周辺との温度差を生じ，マイクロクラックを引き 起こす。また, 結晶相の変態が起こり, 陶材との界面が 不安定になるとも言われている。調整中は，フレームを 水分に浸したり，注水化での作業を行う。結晶相の均一 化を図りたいのであれば，ジルコニアフレーム単体を $1000^{\circ} \mathrm{C}$ 程度で焼成するなどの工夫をしている.

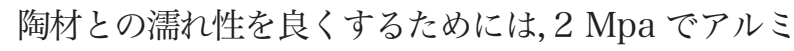
ナサンド処理を行い, 表面の油脂を取り除いたことを確認 してから,ウォッシュベイクなど通常の作業に進みたい. 色調的には，ジルコニアフレームに良くも悪くも透光 性を有するため, SB やオペーシャスボディーなど明度 の高い陶材で骨格(歯髄をイメージすると分かりやすい) を築盛・焼成し，ある程度の反射と拡散を促す。言いか 

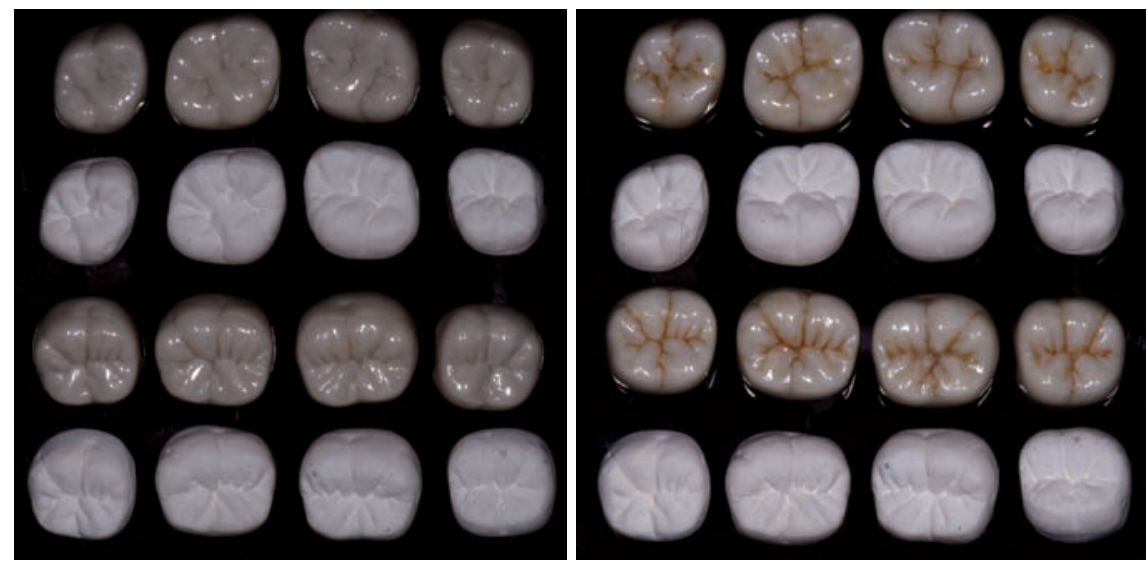

図 12 フルジルコニアクラウンの症例 研磨のみ（左）と，ステインを施したもの（右）。

えれば，骨格をしつかり作製し，ボディー陶材の厚みを 出来るだけ均一にする努力をしたい，そうすることに よって，明度・彩度・色相などのコントロールを行うよ うにしている。

\section{VIII. ジルコニアパーシャルカントゥアクラウン}

市場では抗折強度が高いという理由でジルコニアフル カントゥアジルコニアクラウンがあふれている。しかし ながら，歯牙エナメル質と比較すると 3 倍近い強度を 有するため, 歯牙の過度な咬耗が予想される。 よって, 対合歯との接触に関しては十分な配慮が必要になる。筆 者らは，接触面に陶材やグレーズ材を被覆することに よって対合への環境を整えている（図 12）。

\section{IX．まとめ}

数多くの優位性を有するジルコニア素材を, リスクを 補いつつ最大限有効利用するためには，包括的な捉え方 が必要であろう。歯科医療はトップダウントリートメン トとボトムアップトリートメントを再評価しながら繰り 返されていく，具体的には口腔医学 (Stomatology) と 歯科医学 (Dentistry) の観点から, 炎症・生活習慣な ぞの改善をし，適正な下顎位の模索や歯冠形態の改善を 行っていく，歯科補綴装置を製作するうえでの 3 因子 として, 審美性（骨・軟組織の環境整備, 顎口腔機能, 修復的審美)，材料 (理工）があげられることはすでに 述べた。ジルコニアとういセラミックやガラス素材を長 期に維持・安定させるためには，有効な材質を選択した うえで, 咬合を避けては通れない. 咬合を捉えるうえで, 対合接触のみならず，骨格，顎関節，周囲筋肉群，エン
ド，ペリオ，歯列を含めた支持構造，歯科補綴装置を含 めた材料などを十分に吟味して，再考を繰り返していか なければならない.

今後，ますますデジタル化の波が押し寄せるであろ う。しかし，単純に機械に任せるのではなく，歯科医療 人としての知識や術式が基本となることを忘れてはなら ない，審美とは，機能美と色彩・形態が調和したもので あること。すなわち，人工臟器としての歯科補綴装置を 作製しているという認識を強く持ち続けたいと思う。

今回は，ノリタケ Katana システムとセラビアン Zr （クラレノリタケデンタル，京都，日本）を使用した。 最後に，いまのところ，まだまだ歴史の浅い臨床応用で しか評価できない，今後の動向を注意深く見守っていき たい.

\section{文献}

1) Blatz M, Chapman L, Chiche G, Mercante D. Shear bond strength of veneering ceramics to zirconiumoxide ceramic. J Dent Res 2006; 85 (special issue A) ; Abstract 0888.

2) Yoshida A. All-ceramic restorations: Materials selection and opacity control for esthetic results. QDT 2007; Special issue: 87-101.

3) Christensen GJ. Clinician Report [serial online]. 2008; 1(1 1).

著者連絡先：増田 長次郎

干672-8064 兵庫県姫路市飾磨区細江 120

株式会社力ロス

Tel: 079-243-1 182

Fax: 079-243-1181

E-mail:info@kalos.jp 


\title{
Understanding Zirconia and Comprehensively Applying It to a Wide Dental Practice
}

\author{
Chojiro Masuda
}

Kalos Co., Ltd.

Ann Jpn Prosthodont Soc 4: 148-155, 2012

\section{ABSTRACT}

The coexistence of an excellent prognosis and aesthetics in prosthodontic treatment has been easily accomplished by innovations of surgical and prosthodontic techniques. Esthetics should be established after recovery of the continuity of dentition and the approach to the stomatognathic function.

It is a well-known fact that surgical techniques and choices and the superiorities of prosthodontic treatment have been improved by remarkable developments of new dental materials. Especially, the applications of esthetic restoration and dental implant prostheses have expanded as a result of CAD/CAM progression. Amid this continuing progress, however, in this article I will consider the possibility that at least one field of such original patient-oriented dental care still remains to be exploited.

I will focus on zirconia as the new material and introduce its characteristics of strength, light permeability, and tissue compatibility. Furthermore, I would like to explain techniques to bring out the maximal characteristics of zirconia frameworks, along with the many available clinical applications and the important notices, including dental implant treatments.

I find it important to clarify the role allotment of laboratory and clinical work and to cope with the one patient and his model and to maintain the same consciousness for dentists and dental technicians. I wish to show the necessary points to examine, diagnose, and make treatment plans, to recover the aesthetics and function, and to establish the maintainability I mentioned.

\section{Key words}

esthetic restoration, zirconia, CAD/CAM 